Saudi Journal of Medicine

Abbreviated Key Title: Saudi J Med ISSN 2518-3389 (Print) |ISSN 2518-3397 (Online) Scholars Middle East Publishers, Dubai, United Arab Emirates Journal homepage: https://saudijournals.com/sjm

Original Research Article

\title{
A Study of Nail Changes in Dermatology
}

\author{
Dr. Laxminarayana Bhat
}

Associate Professor, Department of Dermatology, Kanachur Institute of Medical Sciences, Mangalore-Thokkottu-Konaje University Rd, Kotekar Village, Deralakatte, Karnataka 575018, India

DOI: $10.36348 /$ sjm.2020.v05i04.001 | Received: 31.03 .2020 | Accepted: 07.04.2020 | Published: 13.04 .2020

*Corresponding author: Dr. Laxminarayana Bhat

\section{Abstract}

Many nail changes are often found in the Department. They are considered the windows to the inner pathologies. The present study was undertaken to study the different types of nail changes seen in a regular dermatology OPD over a period of six month and prepare an epidemiological data on these findings.

Keywords: Nail, Changes, Dermatology.

Copyright @ 2020: This is an open-access article distributed under the terms of the Creative Commons Attribution license which permits unrestricted use, distribution, and reproduction in any medium for non-commercial use (NonCommercial, or CC-BY-NC) provided the original author and source are credited.

\section{INTRODUCTION}

There are many nail changes that land up in skin OPD. To name a few Onychomycosis (with or without paronychia) Van Der Straten et al., [1,2] and Summerbell et al., [3] both of whom reported the incidence of onychomycosis to be around $50 \%$ of all nail changes. Ramesh et al. [4] as the faster rate of nail plate growth prevents onychomycosis in children. The incidence of onychomycosis is higher in females than in males and the only nail involvement is seen more frequently than in association with skin, hair or systemic disease. Only $37 \%$ of patients of onychomycosis were proven on $30 \% \mathrm{KOH}$ mount as chances as high false negative results are known with this method as mentioned by Fletcher et al., [5, 6]. Paronychia incidence of paronychia is higher in females than males which is mostly due to wet and cold hands due to prolonged contact with water as shown by Esteves et al. [7] and Hellier et al., [8]. The maximum incidence of paronychia is seen between 30 to 39 years of age in our study which is observed by Esteves et al., [17] who reported increased incidence of paronychia between ages 30 to 60. According to Stone et al., [9], paronychia may be seen in children due to thumb sucking. Paronychia mainly presents with nail changes may be present in patients with systemic diseases $(3.0 \%$ of our patients) like pemphigus as mentioned by Engineer et al., [10] and in squamous cell carcinoma as mentioned by Beti et al., [11]. Subungual Hyperkeratosis The incidence of subungual hyperkeratosis increases significantly with age with the maximum incidence being above 40 years of age. Pitting is more common in males than females and the association is significant. Pitting is more common in less than 30 years of age and is highly associated with skin and hair changes according to Nanda et al., [12] and Kumar et al., [13] who have described higher incidence of pitting in children suffering from psoriasis. Pterygium males are more affected than females but the association is not significant. All patients of pterygium are associated with skin and/or hair changes which is similar to reports of pterygium in association with lichen planus by Samman et al., [14], with graft versus host disease by Little et al. [15] and with type II lepra reaction by Patki et al., [16]. Onycholysis The incidence of onycholysis is equal in males and females. There is a bimodal peak of onycholysis in our study which can be explained on the basis of multiple causes of onycholysis which includes trauma, fungal infection, eczema, drug reactions, maceration, photo-onycholysis [17], hypothyroidism [18], hyperthyroidism [19], trauma [20], drugs like 5-FU [21], doxycycline [22-24], retinoids [25] and chemotherapy [26]. Onychoschizia no significant difference in the incidence of onychoschizia in males and females which was reported by Waillis et al., [27] which says that onychoschizia can be found in $27 \%$ - $35 \%$ of normal adult females. The incidence of onychoschizia is maximum between 30-39 years of age which can be explained on basis of females who repeatedly soak their hands in water for domestic work and develop onychoschizia as explained by Waillis et al., [28]. Onychoschizia is associated more significantly with only nail changes than with skin/hair or systemic disease. Melanonychia shows presence of melanonychia to be significantly higher in males $(7.1 \%)$ than females $(3.0 \%)$ and probably be attributed to multiple drugs or systemic diseases that these patients had. The incidence of melanonychia is significantly more in less than 30 years of age which is probably due to racial pigmentation which was reported 
in study by Monash et al., [29] which says that $77 \%$ of Afro-Carribeans over 20 years of age have longitudinal melanonychia and the prevalence of which increases to almost $100 \%$ by 50 years. The incidence of melanonychia is significantly more in association with systemic disease than with only nails or in association with skin and/or hair. This is possibly due to the multiple drugs which can cause pigmentation of the nails as demonstrated by Gallais et al., [30]. Half and Half nail shows significantly greater incidence of half and half nails in males $(0.9 \%)$ than females $(0.2 \%)$ with all patients having associated systemic disease as shown in study by Daniel et al., [31]. Trachyonychia shows equal incidence of trachyonychia in both males and females with maximum incidence of trachyonychia between $30-39$ years of age which is probably due to its association with dermatological conditions like alopecia areata [32], lichen planus and psoriasis which usually present in this age group. Onychogryphosis, Less number of males of more than 50 years presented with onychogryphosis with only nail changes. This finding was observed by Cohen et al., [33], Dawber et al., [34] and Gilchrist et al., [35] that onychogryphosis is a nail disorder of the elderly. Subungual melanoma. These patients had a positive Hutchinson's sign which is a strong clinical marker of subungual melanoma as shown by Kopf et al., [36]. This study puts in an effort to study the nail changes that we encounter in the skin OPD.

Aims and Objectives: To study the nail changes in Dermatology

\section{MATERIALS AND METHODS}

- This study was done in the Department of Dermatology, Kanachur Institute of Medical Sciences, Deralakatte, Mangalore.

- $\quad$ This study was done from September 2019 to December 2019.

- All the nail changes were identified and reported.

- Sixty patients who attended the OPD were the subjects.

\section{RESULTS}

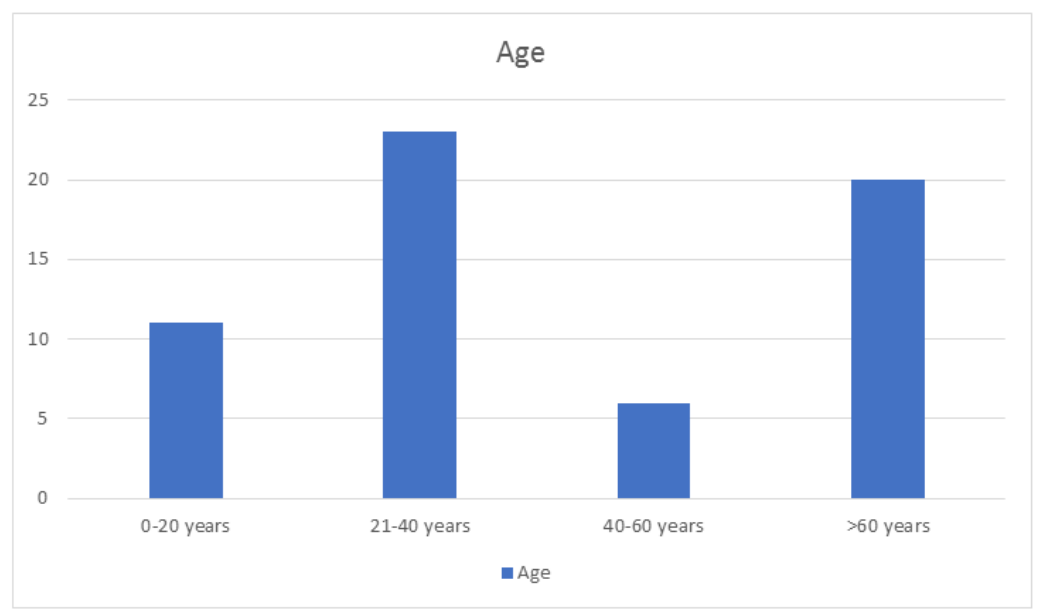

Graph-1: Age distribution

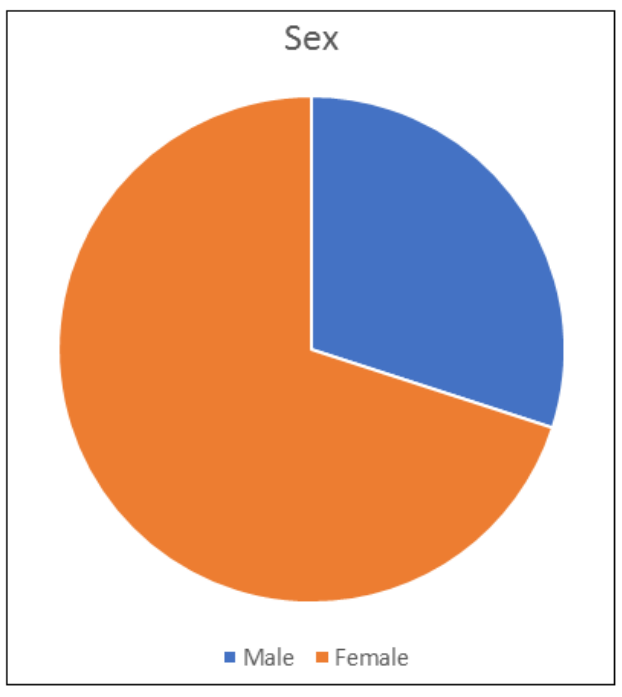

Graph-2: Sex Distribution
Table-1: Frequency of Nail Changes

\begin{tabular}{|l|l|}
\hline Onychomycosis & 30 \\
\hline Onychomycosis and paronychia & 11 \\
\hline Paronychia & 4 \\
\hline Subungual hypertrophy & 1 \\
\hline Pitting & 2 \\
\hline Half and half nails & 3 \\
\hline Onycholysis & 2 \\
\hline Onychoschizia & 4 \\
\hline Melanonychia & 1 \\
\hline Pterygium & 1 \\
\hline Trachyonychia & 1 \\
\hline
\end{tabular}

\section{DISCUSSION}

The long and shapely nails depicted in early Chinese art speak of the relative importance people gave to nail care in ancient times [37]. However, nail cosmetology as it is evolving today is a fairly recent 
development [38]. The chief function of the nail in man is that of protection. It protects the terminal phalanx and the fingertip and gives deftness and precision in picking up small objects. The nail also serves to augment the sensation of touch [39]. The nail apparatus develops and matures from the primitive epidermis between the ninth and twentieth weeks of intrauterine life [40]. As a structure the nail is first recognisable in a ten -week-old embryo [41] as primary nail field of proliferative ectoderm on the tip of the terminal segment of the digits. Continued proliferation of the nail fold in the proximal direction progressively defines their final dorsal position. Due to a relatively slow rate of growth, the field become somewhat depressed and the epidermis overlaps their side and proximal end to form of nail fold. The proximal part of each nail fold proliferates to form the root of the nail, and this soon becomes formative zone or germinative portion of the nail. And from this germinative zone, the actual substance of the nail in formed continuously. Keratin synthesis can be identified in the nail unit from of the earliest stage of embryonic differentiation [41]. Fetal growth of the nails is gradual, their edges merely reaching the tips of the digits at birth and the finger nails appearing rather longer than the toe nails [41]. The present study was undertaken to study the different types of nail changes seen in a regular dermatology OPD over a period of six month and prepare an epidemiological data on these findings.

\section{CONCLUSION}

The study successfully finds the commonest nail changes that is brought to skin OPD.

\section{REFERENCES}

1. Guidelines/Outcomes Committee. (1996). American Academy of Dermatology. Guidelines of care for nail disorders. $J$ Am Acad Dermatol, 34, 375-8.

2. Vander, M. S., Hossain, M. A., \& Ghannoum, M. A. (2003). Cutaneous infections dermatophytosis, onychomycosis, and tinea versicolor. Infectious disease clinics of North America, 17(1), 87-112.

3. Summerbell, R. C., Kane, J., \& Krajden, S. (1989). Onychomycosis, Tinea Pedis and Tinea Manuum Caused by Non- Dermatophytic Filamentous Fungi Nicht- DermatophytenFadenpilze als Erreger von Onychomykosen, Tinea pedis und Tinea manuum. Mycoses, 32(12), 609-619.

4. Ramesh, V., Reddy, B. S., \& Singh, R. (1983). Onychomycosis. Int J Derrmatol, 22:148-152.

5. Fletcher, C. L., Hay, R. J., \& Smeeton, N. C. (2004). Onychomycosis: the development of a clinical diagnostic aid for toenail disease. Part I. Establishing discriminating historical and clinical features. British Journal of Dermatology, 150(4), 701-705.

6. Esteves, J. (1959). Chronic paronychia. Dermatologica, 119:229-231.
7. Hellier, F. F. (1955). Chronic paronychia: aetiology and treatment. BMJ, ii: 1358-60.

8. Stone, O. J., \& Mullins, J. F. (1968). Chronic paronychia in childhood. Clin Pediatr, 7:104-107.

9. Engineer, L., Norton, L. A., \& Ahmed, A. R. (2000). Nail involvement in pemphigus vulgaris. Journal of the American Academy of Dermatology, 43(3), 529-535.

10. Betti, R., Vergani, R., Inselvini, E., Tolomio, E., \& Crosti, C. (2000). Subungual squamous cell carcinoma mimicking chronic paronychia. European Journal of Dermatology, 10(2), 149-50.

11. Nanda, A., Kaur, S., Kaur, I., \& Kumar, B. (1990). Childhood psoriasis: an epidemiologic survey of 112 patients. Pediatric dermatology, 7(1), 19-21.

12. Kumar, B., Jain, R., Sandhu, K., Kaur, I., \& Handa, S. (2004). Epidemiology of childhood psoriasis: a study of 419 patients from northern India. International journal of dermatology, 43(9), 654-658.

13. Samman, P. D. (1969). Idiopathic atrophy of the nails. British Journal of Dermatology,81(10), 746-749.

14. Liddle, B. J., \& Cowan, M. A. (1990). Lichen planus- like eruption and nail changes in a patient with graft- versus- host disease. British Journal of Dermatology, 122(6), 841-843.

15. Patki, A. H., \& Mehta, J. M. (1989). Pterygium unguis in a patient with recurrent type 2 lepra reaction. Cutis, 44(4), 311-312.

16. Baran, R., \& Juhlin, L. (1987). Drug-induced photo-onycholysis: three subtypes identified in a study of 15 cases. Journal of the American Academy of Dermatology, 17(6), 1012-1016.

17. Fox, E. C. (1940). Diseases of the nails: report of cases of onycholysis. Archives of Dermatology and Syphilology, 41(1), 98-112.

18. Luria, M. N., \& ASPER, S. P. (1958). Onycholysis in hyperthyroidism. Annals of internal medicine, 49(1), 102-108.

19. Heinmann, H., \& Silverberg, M. G. (1941). Onycholysis in fur workers. Arch Dermatol Syphilol, 44: 426-8.

20. Shelley, W. B. (1972). Onycholysis due to 5fluorouracil. Acta Derm Venereol (Stockh), 52:320-322.

21. Schultz, H. D. (1966). Hereditary partial onycholysis and hard nails. Dermatol Wochenschr, 152:766-768.

22. Franks, S. B., Coton, H. J., \& Mirkin, W. (1971). Photo-onycholysis due to tetracycline. Arch Dermatol, 103, 520.

23. Baran, R., \& Juhlin, L. (2002). Photoonycholysis. Photodermatol Photoimmunol Photomed, 18: 202-207.

24. Önder, MO Öztaş, P Öztaş, M. (2001). Isotretinoin-induced nail fragility and onycholysis. Journal of dermatological treatment, 12(2), 115-116. 
25. Minisini, A. M., Tosti, A., Sobrero, A. F., Mansutti, M., Piraccini, B. M., Sacco, C., \& Puglisi, F. (2003). Taxane-induced nail changes: incidence, clinical presentationand outcome. Annals of oncology, 14(2), 333-337.

26. Wallis, M. S., Bowen, W. R., \& Guin, J. D. (1991). Pathogenesis of onychoschizia (lamellar dystrophy). Journal of the American Academy of Dermatology, 24(1), 44-48.

27. Monash, S. (1932). Normal pigmentation in the nails of the Negro. Archives of Dermatology and Syphilology, 25(5), 876-881.

28. Gallais, V., Lacour, J. P., Perrin, C., Ghanem, G., Bodokh, I., \& Ortonne, J. P. (1992). Acral hyperpigmented macules and longitudinal melanonychia in AIDS patients. British journal of dermatology, 126(4), 387-391.

29. Daniel III, C. R., Sams Jr, W. M., \& Scher, R. K. (1985). Nails in systemic disease. Dermatologic clinics, 3(3), 465-483.

30. Baran, R. (1981). Twenty-nail dystrophy of alopecia areata. Archives of Dermatology, 117(1), $1-11$.

31. Cohen, P. R., \& Scher, R. K. (1992). Geriatric nail disorders: diagnosis and treatment. Journal of the American Academy of Dermatology, 26(4), 521531.

32. Dawber, R. P. R., Bristow, I., \& Mooney, J. (1996). The Foot: Problems in Podiatry and Dermatology. London: Dunitz.
33. Gilchrist, A. K. (1979). Common foot problems in the elderly. Geriatrics, 34:67-70.

34. Kopf, A. W. (1981). Hutchinson's sign of subungual malignant melanoma. Am Journal Dermatopathol, 3:201-202.

35. Mahdihassan, S. (1990). The manicuring system of keeping long nails originating from China. The American journal of Chinese medicine, 18(03n04), 197-199.

36. Chopra, A. 1998). Lifestyle -cosmetics. Funky colors to flaunt. India today, 70-71.

37. Dawber, R. P. R., Baran, R., \& De Berker, D. (1994). Science off nail apparatus. In: Baran, R., Dawber, R. P. R., editors, diseases of the nails and their management. 2nd ed. Oxford: Blackwell Scientific Publications; 1-34.

38. Dawber, R. P. R., Baran, R., de Berker, D. (1998). Disorders of nails. In: Champion, R. H., Burton, J. L., Burns, D. A., \& Breathnach, S. M., editors Textbook of dermatology. 6th ed. Oxford : Blackwell Science; 2815-68

39. Zaias, N. (1963). Embryology of the human nail. Arch dermatol, 87:37-42

40. Moll, I., Heid, H. W., Franke, W. W., \& Moll, R. (1988). Patterns of expression of trichocytic and epithelial cytokeratins in mammalian tissues: III. Hair and nail formation during human fetal development. Differentiation, 39(3), 167-184.

41. William, P. L., Warwick, R., \& Dyson, M. editors. (1989). Gray's anatomy. 37th ed. Edinburgh: Churchill livingstone. 